\title{
Preceptorship in nursing-midwifery: a training-intervention in health work
}

\author{
Preceptoria em enfermagem obstétrica: formação-intervenção no trabalho em saúde \\ Preceptoría en enfermería obstétrica: formación-intervención en trabajos de salud
}

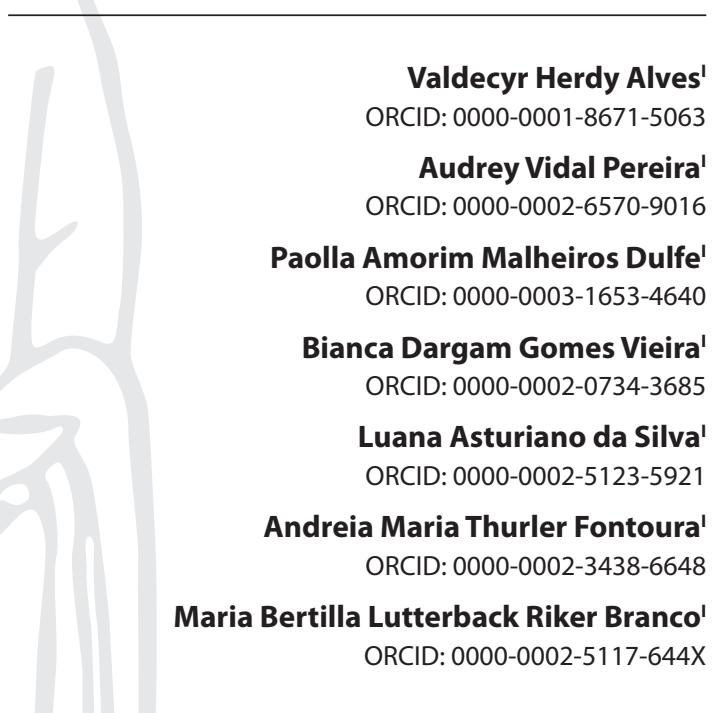

'Universidade Federal Fluminense. Niterói, Rio de Janeiro, Brazil.

How to cite this article:

Alves VH, Pereira AV, Dulfe PAM, Vieira BDG, Silva LA, Fontoura AMT, et al. Preceptorship in nursingmidwifery: a training-intervention in health work.

Rev Bras Enferm. 2020;73(Suppl 6):e20190661. doi: http://dx.doi.org/10.1590/0034-7167-2019-0661

Corresponding author:

Paolla Amorim Malheiros Dulfe

E-mail: paolla_amorim@yahoo.com.br

EDITOR IN CHIEF: Antonio José de Almeida Filho ASSOCIATE EDITOR: Marcos Brandão

Submission: 09-27-2019 Approval: 04-26-2020

\begin{abstract}
Objectives: to analyze how certified nurse-midwives identify preceptorship in a nursingmidwifery enhancing course conducted by the Universidade Federal Fluminense as a possibility of training to promote institutional support and intervention. Methods: a descriptive, exploratory research with qualitative approach. Six certified nurse-midwife preceptors from the Nursing-Midwifery Enhancing Course participated in the study in 2019. Two public maternity hospitals in Rio de Janeiro were settings of the research. Individual interview and thematic content analysis were used to collect and analyze data. Results: exchange of knowledge between preceptors and trainees encouraged learning and reflection stemming from delivery and birth, contributing to expansion of autonomy and professional leading role in training, health care, and management. Final Considerations: collective meetings that promote work analysis and value the performance of certified nurse-midwives have led to intervention processes and institutional support in maternity hospitals in Rio de Janeiro, Brazil. Descriptors: Obstetric Nursing; Humanization of Assistance; Health Administration; Professional Training; Work Engagement.
\end{abstract}

\section{RESUMO}

Objetivos: analisar como as enfermeiras obstétricas identificam a preceptoria em um Curso de Aprimoramento em Obstetrícia, realizado pela Universidade Federal Fluminense, como possibilidade de formação com vistas ao apoio e intervenção institucional. Métodos: pesquisa descritiva, exploratória, com abordagem qualitativa. Seis enfermeiras obstétricas preceptoras do Curso de Aprimoramento para Enfermeiras Obstétricas participaram do estudo em 2019. Duas maternidades públicas da região metropolitana do Rio de Janeiro foram cenários da pesquisa. Entrevista individual e análise de conteúdo temática foram utilizadas para coleta e análise das informações. Resultados: troca de saberes entre enfermeiras obstétricas preceptoras e enfermeiras obstétricas aprimorandas fomentaram aprendizados e reflexões no âmbito do parto e nascimento, contribuindo com a ampliação da autonomia e protagonismo profissional no processo de formação, atenção à saúde $e$ gestão. Considerações Finais: encontros coletivos que fomentam análise do trabalho e valorizam a atuação de enfermeiras obstétricas têm suscitado processos de intervenção e apoio institucional em maternidades no Rio de Janeiro, Brasil.

Descritores: Enfermagem Obstétrica; Humanização da Assistência; Cogestão Administrativa; Formação Profissional; Engajamento no Trabalho.

\section{RESUMEN}

Objetivos: analizar cómo las enfermeras obstétricas identifican la preceptoría en un curso de mejora obstétrica, realizado por la Universidade Federal Fluminense, como una posibilidad de capacitación con miras a apoyo e intervención institucional. Métodos: investigación exploratoria descriptiva con enfoque cualitativo. Seis enfermeras obstétricas que fueron instructoras en el Curso de Mejoramiento para Enfermeras Obstétricas participaron en el estudio en 2019. Dos hospitales públicos de maternidad en la región metropolitana de Río de Janeiro fueron los entornos de investigación. Se utilizaron entrevistas individuales y análisis de contenido temático para recopilar y analizar informaciones. Resultados: el intercambio de conocimientos entre las enfermeras obstétricas preceptoras y las enfermeras obstétricas alumnas fomentó el aprendizaje y las reflexiones en el ámbito del parto y el parto, contribuyendo a la expansión de la autonomía y el protagonismo profesional en el proceso de capacitación, atención médica y gestión. Consideraciones Finales: las reuniones colectivas que fomentan el análisis del trabajo y valoran el trabajo de las enfermeras obstétricas han elevado los procesos de intervención y el apoyo institucional en los hospitales de maternidad en Río de Janeiro, Brasil.

Descriptores: Enfermería Obstétrica; Humanización de la Atención; Administración en Salud;Capacitación Profesional; Compromiso Laboral. 


\section{INTRODUCTION}

The use of strategies to empower, or improve people in the workplace has been used by management in health institutions due to the need to foster dialogues and experiences that approach the practical reality. It also seeks to avoid unnecessary displacements and raise operationalization of actions engaged with the perspective of qualifying processes of change in daily work.

In the context of delivery and birth, the World Health Organization (WHO) ${ }^{(1)}$ and the Ministry of Health $(\mathrm{MoH})$ in Brazil have encouraged implementing actions based on the Brazilian National Humanization Policy of care and management of the Brazilian Health System (Sistema Único de Saúde, abbreviated SUS) (Política Nacional de Humanização, abbreviated PNH, 2003), the Prenatal and Birth Humanization Program (Programa de Humanização de Pré-Natal e Nascimento, abbreviated PHPN, 2002), the Brazilian National Policy for Comprehensive Women's Health Care (Política Nacional de Atenção Integral à Saúde da Mulher, 2004 and 2011) and the Stork Network (Rede Cegonha, 2011) ${ }^{(2-3)}$. Thus, they signal permanent need to institutionalize a model of delivery care, whose health practices qualify a less interventionist and more humanized care network ${ }^{(4-5)}$.

To strengthen action and training continuity, MoH has invested efforts from initiatives in partnership with the Universidade Federal Fluminense (UFF) and the Universidade Federal de Minas Gerais (UFMG), in order to operationalize NursingMidwifery Enhancing Courses (NMEC') across the country ${ }^{(6-8)}$.

In 2017, MoH, the Ministry of Education, the Instituto Fernandes Figueira da Fundação Osvaldo Cruz, the Brazilian Association of University and Teaching Hospitals, the Brazilian Hospital Services Company, and UFF had as initiative to implement the project entitled Enhancement and Innovation in Care and Teaching in Midwifery and Neonatology (Aprimoramento e Inovação no Cuidado e Ensino em Obstetrícia e Neonatologia, abbreviated APICEON/MoH). The project expanded enhances qualification of health care, management, and training in university hospitals and teaching maternity hospitals( ${ }^{(9)}$.

As the importance of this training process is founded, which has encouraged changes in the midwifery model in SUS across the country, it becomes clear the need to look at the operational performance of practical field supervision and certified nursemidwives, who act as preceptors in NMEC financed by $\mathrm{MoH}$ and carried out by UFF.

It should be considered that the methodological proposal used as a support to improve care and teaching in midwifery, from APICEON/MoH, brings in its theoretical anchorage the warning to also take into account the potentialities of individuals in order to improve communicative interactions, active in-service professional participation, and the capacity to mobilize towards changes in a perspective of work co-management ${ }^{(10-13)}$.

1 a In the course of the text, the use of "enhanced certified nurse-midwife" aims to identify certified nurse-midwives who, because they are specialists with technical knowledge acquired by Lato Sensu education, attended the course in a perspective of professional improvement in midwifery. The argument to use the term "enhanced" is ratified to refer to this group that updated technical-scientific studies and professional practices based on contemporary scientific evidence $\mathrm{e}^{(6-8)}$
However, the central problem is the mismatch or existence of gaps between the ways of carrying out preceptorship under the traditional teaching logic and the current proposal operationalized in SUS. However, according to the continuing education based on public policy, which dialogues with training-intervention models, we seek to problematize the work processes in health by providing analysis, reflections, dialogues, and service and professional training participation ${ }^{(14)}$.

Giving meaning to social and institutional relations through reflective dialogue and exchange of experience and knowledge makes it possible to reduce pedagogical distancing between care professionals, training, and management. To make teaching-learning movements based on their own work situations is to call for resources invested in meetings and dialogues to operate reflected practices capable of transforming realities in the daily life of institutions.

In other words, this approach, whose theoretical model is anchored in the critical-reflexive-dialogical conception and in the collective learning process, enables professional engagements responsible for raising reflections on one's own performance and implementing ways of intervening in workplace and health education. Thus, the dialogical theory of reflection and action proposed by Paulo Freire makes it possible to base practices of subjects who, from a collaborative perspective, meet for the transformation of the world ${ }^{(15)}$.

Preceptorship refers to a more experienced worker's performance who is concerned with a future professional's education, thus admitting the need for several skills to identify weaknesses and encourage trainee participation ${ }^{(16)}$. It is a support process that occurs when a more experienced person works alongside another in order to provide clinical support and guidance in favor of teaching and learning new skills, with a view to taking over an independent and quality professional practice ${ }^{(17)}$.

Therefore, preceptorship commitment needs to go beyond transfer of information, demonstration of procedures, organizational surveillance and technocratic qualification. It must also imbue itself by working on reflections that refer to social, cultural, and power aspects.

In this case, the preceptorship developed by certified nursemidwives in delivery and birth in maternity hospitals in Rio de Janeiro (RJ), from conducting NMECs across the country, should be open to the conception of work as an activity and service relationship that, in a certain way, dialogue with NHP and the Continuing Education in Health Policy (Política de Educação Permanente em Saúde, abbreviated PNEPS) ${ }^{(18)}$. To some extent, this function needs to be encouraged to make a link between teaching/training, care/assistance, and management of teaching maternity hospitals based on professional dialogue, supporting the collective analysis of health work ${ }^{(11)}$.

The work of preceptorship in midwifery can and must be linked to the concept of institutional support. It aims at the production of subjects in relation to work and points out aspects about form of organization, in-service autonomy, and communication/dialogue between care and management professionals and training.

This perspective of training based on co-management strategies and dialogues on work can contribute to encouraging political-methodological processes that enhance active participation of care and training of professionals in order to act as institutional supporters. Collective involvement to ensure the 
means for training/teaching/preceptorship ends up providing conversations about work that, in turn, contribute to the induction of new ways of producing subjects/teams ${ }^{(10,12-13)}$.

In this context, they can contribute by mediating situations of tension and institutional conflicts, allowing to foster changes in daily relationships through movements that allow balance of forces and power, mutually influencing conviviality at work and in education ${ }^{(19)}$.

They provoke the possibility to reorganize performance and ways of exercising management that, to some extent, characterize tools to strengthen midwifery ${ }^{(17)}$. Its theoretical perspective is the concepts of education-intervention as a field of collective analysis of health work ${ }^{(10)}$ and Paulo Freire principles ${ }^{(15)}$. Such principles underlie a reference that articulates pedagogical practice in transforming reality, representing in this study the spaces of preceptorship and co-management in maternity hospitals ${ }^{(12-13)}$ where NMEC/MoH/UFF were performed.

\section{OBJECTIVES}

To analyze how certified nurse-midwives identify preceptorship in a NMEC conducted by the Universidade Federal Fluminense as a possibility of training to promote institutional support and intervention.

\section{METHODS}

\section{Ethical aspects}

The Research Ethics Committee of the Hospital Universitário Antônio Pedro of UFF approve this study, under Opinion $3,434,805 / 2019$, as provided for in the Resolution 466/2012 of the Brazilian National Health Council (Conselho Nacional de Saúde). After presenting the scope of the research, participants were invited to compose their workplaces. To preserve their confidentiality, anonymity, and reliability, the interviewees received an alphanumeric coding (e.g.: P1... P6), in addition to ensuring voluntary participation by signing the Informed Consent Term.

\section{Type of study}

This descriptive, exploratory, and qualitative research was guided by COREQ $^{(20)}$, having as participants certified nurse-midwives preceptors from NMEC funded by $\mathrm{MoH}$ and conducted by the Escola de Enfermagem Aurora de Afonso Costa of UFF.

\section{Study setting}

The setting comprises two public maternities in Rio de Janeiro, one linked to the Municipal Health Department (MHD-RJ) and the other to the Fundação Municipal de Saúde de Niterói, which were a practical field of NMEC (MoH/UFF).

\section{Data collection and organization}

The participants considered eligible for the study should meet the following inclusion criteria: being certified nurse-midwives, preceptors from NMEC/MoH/UFF, servants of these maternity hospitals with specialist registration at the Regional Nursing Council-RJ (Conselho Regional de Enfermagem). Those who were on vacation or licensed due to health reasons were excluded, as well as of the eight (8) eligible, six (6) certified nurse-midwife preceptors participated, since two (2) were on medical leave. The data collection period occurred in July 2019.

Semi-structured interview was used with questions about perceptions of certified nurse-midwife preceptors from NMEC/ $\mathrm{MoH} /$ UFF about continuing education along the lines of trainingintervention for certified nurse-midwives. The interviews lasted approximately 30 to 50 minutes, being recorded with digital resources and transcribed in full. They were performed individually according to pre-agreed time in reserved places in maternity hospitals, where the researcher remained silent so as not to intervene in the process of collecting information.

\section{Data analysis}

The reports were analyzed through content analysis in the thematic modality ${ }^{(21)}$, whose phases were: 1 ) pre-analysis of the statements; 2 ) exploration of the material and treatment of the results; 3 ) inference and interpretation.

Simple computerized resources were used to organize and encode the material (colorimetry in Microsoft Word ${ }^{\circ}$ ), which made it possible to elect the following Signified Units: Perception of certified nurse-midwives about the practice of preceptorship; Characterization of preceptorship as institutional support and intervention; Changes in the institution's work process; Exchange of knowledge and experiences; Expansion and strengthening of professional performance. The following thematic nucleus emerged: Preceptorship in the UFF's Enhancing Course as a possibility of training with a view to institutional support.

This way it becomes possible to identify two thematic categories: 1) Participation of certified nurse-midwife preceptors in delivery and birth as possibilities for institutional support and intervention; 2) The role of certified nurse-midwives in the training process: ways of preceptorship that increase visibility and professional performance.

\section{RESULTS}

The group composed of six (6) certified nurse-midwife preceptors from NMEC/MoH/UFF were between 28 and 53 years old. They had on average seven (7) years of experience working in nursing-midwifery and attended specialization courses in midwifery in public institutions in the State of Rio de Janeiro, completed in an average period of five years. The statements of certified nurse-midwives about preceptorship in an update/ enhancement course financed by $\mathrm{MoH}$ made it possible to identify perspectives of intervention and institutional support in delivery and birth, and to expand autonomy and professional leadership.

\section{$1^{\text {st }}$ Category - Participation of certified nurse-midwife preceptors in delivery and birth as possibilities of insti- tutional support and intervention}

Looking at training process in the setting of delivery and birth, from the preceptorship performed by certified nurse-midwives 
in maternity hospitals following APICEON/MoH, practical fields of NMEC/MoH/UFF in Rio de Janeiro, allowed considering the work with the perspective of strengthening collectives and changing the institutional daily reality.

In a relationship of reciprocal implications, it was possible to observe that, from the follow-up previously carried out by the course management team in maternity hospitals, preceptorship was encouraged to perform differentiated training and provoke changes that would generate different meanings in institutional relations.

On the one hand, it can be observed that the group referred to the changes caused in the work process of the institution that welcomes enhanced certified nurse-midwives from other states. On the other hand, they pointed out that the changes observed and discussed in the field of care would also be able to affect and contribute to transform the units of origin of professionals who were updating/enhancing through participation in the course:

The biggest movement occurs in practice... which the course... APICEON brings up the discussion... it's the questions, the questions... how is it correct... what has been studied that is right... which is recommended... why don't we do it... I think it affects the routine of the institution... and makes people reflect and rethink... and discuss work... work processes. (P4)

The whole unit ends up getting involved in the proposal... it is notorious to notice that there is a provocative movement to change the work process of the institution that receives the trainees, as it ends up involving the entire team, both health professionals and administrators, the reception/concierge even the people in the cafeteria... (P1)

However, they pointed out that these changes, specifically those involving the medical category, have still been experienced with some resistance:

\begin{abstract}
All this process carried out by nursing-midwifery... we can't get this process done at the unit as a whole... we can't get the medical team to work on this logic of humanized labor assistance... our big problem today is to make the unit respect a care protocol humanized integral to delivery and birth... teamwork. (P1)
\end{abstract}

However, resistance is not unilateral, since certified nursemidwives from other Brazilian states bring with them something that confuses with this reluctance which, in turn, distances them from the relationships among the team, culminating in this reciprocal resistance that becomes the object of dialogue and analysis in the training process.

Despite the movement... of in-service changes... I still think there is a medical resistance present in the speech on enhancing... due to the way they [enhancing] interpret how labor should be... that labor is a problem, and is not physiological. They cannot see how their role [doctors] and the role of the certified nurse-midwife in the same care setting are important. (P3)

It can be seen from the following reports that, even though experiencing situations of tension and change, professionals were encouraged to dialogue about their daily lives during and after the time in which training practices occurred. They also reflected on the reciprocal influence that had repercussions on the unit's training process, because, in a certain way, care and management professionals also learned and exchanged experiences with the coming of workers from other places in the country.

So, we preceptors, who are there together, supervisors, and also the other professionals who are involved in this context... they need a certain way to look for things that are current. So, this makes the unit... women... they benefit! Because when there are outsiders to intervene, even if only to observe our practice, our performance is interfered with... (P1)

Preceptorship [the enhancement course] causes change... when we start teaching, we become a showcase... is exposed to all that is good and all that is bad in the service. I believe this makes all professionals rethink their attitudes... when we teach, learn, expose, and also absorb experiences... not only as a preceptor, but the whole team. So, we start doing it differently and start seeing how much it works... (P6)

Such influences were mentioned from APICEON/MoH and NMEC/MoH/UFF strategies through the need to look the workplace with the perspective of dialogue regarding it in the institutional daily reality. Certified nurse-midwife preceptors pointed out that, after the beginning of the course, the goal of organizing meetings of/among workers to discuss the daily life of performance in maternity hospitals was a commitment of care/assistance, management, and training professionals. In addition, they highlighted the importance of support from APICEON/MoH, in this case, the seal of the same, which made it essential to guarantee the intervention process. Initiatives from the federal level encouraged changes.

I believe that as we hold monthly meetings with all members of the teams... I think that everything we have been doing has had an effect. [...] / also believe that a greater presence also of members from outside... from APICEON... more present in the institution, in terms of meetings... will also have a legal effect. (P3)

As it is a course, preceptorship, APICEON is a $\mathrm{MoH}$ project... this has a different weight when you enter an institution with $\mathrm{MoH}$ 's logo, support, work proposal... and make it let management feel, I don't say thank you, but feel uncomfortable as it needs to make and rethink the change... when the APICEON team is making an intervention, bringing a group, calling for a meeting, sitting with the management... this has a very heavy weight and bothers. (P4)

This involvement, especially in relation to the request for a greater presence of the university/MoH, has encouraged the exchange of knowledge and experiences among in-service workers and implemented a movement in favor of expanding collective meetings in the perspective of thinking about work with belonging and not as a repetition of tasks and guarantee of protocols. In this case, these meetings provoked the activity of reciprocal changes in the context of training, management, and care.

Incentive to develop the improvement course... because I see women in my unit giving birth differently... there is a need to create protocols, updates, practices carried out at the unit. APICEON's enhancement course makes it possible to think about work and not only repeat the work. $(\mathrm{P} 1)$ 
The following reports show that the way of relating to work in institutions begins to be experienced in a more inventive and collaborative way, contributing to reflect and dialogue about daily practice:

It causes us to rethink, reassess the process of training and practice. So, we are all the time in transformation... all the time in intervention. We are all the time connected to practice and training... understanding that everyone is already specialists. (P2)

Changes in the way health professionals deal with conflicts... in the process... in management... in training... and also in trainees and preceptors... (P3)

This movement, which instigates work analysis processes, stimulates the understanding that using it from the workers themselves, in the sense of providing assistance and ways of teaching/training reflective, contributes towards expanding transformations beyond institutional walls. Thus, reciprocal changes can occur both in the relationships between professionals who are already in maternity hospitals and receive enhanced certified nurse-mid wives, as well as in the institutions that sent these specialists to the course:

The incentive we have by the institution, I think it is very personal... it is when you like what you do, when you want all women to have this respectful assistance with the use of technologies... with respect. So, you want this to spread to the other institutions. (P5)

Understanding that indication was made from an institutional commitment between management, APICEON/MoH, and enhanced certified nurse-midwives, raises the possibility of individual and collective commitment, as explained in the following statement:

Intervention for those who come, for those who propose to modify this model that is accustomed, and be able to transform the workplace when it returns... in-service change. Or just to strengthen the practice [...] there will also be intervention in ourselves, in management, in everything. (P6)

Therefore, when enhanced certified nurse-mid wives who came to attend the enhancing course return to their home institution must find support, in order to ensure individual involvement and collective engagement in the processes of change.

\section{$2^{\text {nd }}$ - The role of certified nurse-midwives in the training process: ways of preceptorship that increase visibility and professional performance}

As for the performance of preceptorship at the course financed by $\mathrm{MoH}$ (2018-2019), it was possible to identify that certified nurse-midwife preceptors expressed a consolidated teachinglearning relationship through effective monitoring of delivery and birth. Therefore, preceptorship actions were configured from the professional practice itself.

By effecting the direct exemplifying of professional performance, certified nurse-midwife preceptors used dynamic teaching-learning resources such as cardiotocography, suture, dystocia management, bleeding complications, aromatherapy, and discussion of protocols.
I have been doing dynamics related to the daily work... we do it when there is no delivery assistance, we are always talking about suture techniques, about cardiotocography reading, about dystocia, about bleeding, discussing protocols that should not be closed... discussing what is done in practice. $(\mathrm{P} 2)$

Need to carry out suture workshops, we talk about spinning babies... because we use it here in our practice... spinning babies, aromatherapy [...] these were strategies, when you are watching our labor monitoring and delivery... then this need arose on the part of them to discuss. (P5)

Sharing up-to-date scientific knowledge aroused reflections on the part of some interviewees, who, to some extent, contributed to strengthen the image of certified nurse-midwives in the working relations in the course's maternity hospitals or exemplify positions of professional independence in the relationship with enhanced certified nurse-midwives.

We have a lot of autonomy with the whole team... medical team, with technicians... we have a lot of exchange... we have the respect of the teams... we start introducing the enhancing group to the entire service. (P6)

The relationships of preceptors allowed us to experience exchanges of knowledge between professionals from different realities of the country. Both the groups of certified nurse-midwife preceptors and enhanced certified nurse-midwives are instrumentalized to act differently in the course's maternity hospitals and, respectively, in the institutions of origin.

Providing these health professionals with a little bit of practice, a little bit of understanding about management, a little bit of experience of those who have already done this institutionalization process of in-service nursing-midwifery assistance. (P4)

I think it's a lot of exchange. Each person talks about their own reality... so this is a very big exchange between services. (P5)

It was also possible to record that nurses perceived that the preceptorship actions under the influence of NMEC/MoH/UFF, to some extent, strengthened their own professional performance. To implement the activities directed by the course, it was necessary to carry out a preceptorship exercise through collective discussions and reflections on the problems related to practice and those imbricated to work and continuing education.

In this context, preceptorship made it possible for certified nurse-midwives to get closer to the other professionals and managers of the institutions receiving the course. It also promoted meetings that, in a way, contributed to reflect on daily practice.

In a correlated perspective, the interviewed group understood that preceptorship was also developed through the involvement of certified nurse-midwife preceptors with management and other professionals. Also, the focus would be to mediate relationships with a view to operationalizing the course and boosting processes that contribute to structural changes.

I have tried to discuss with them [trainees] why and how we can see this problem situation, seeking to understand the problem or the way 
to solve it in a way to think together, to change together, changing the structure and practices of the units [...] the relationship between nursingmidwifery preceptorship and delivery management professionals can be affected... a positive way where there is a management with real interest in having a change in structure. (P1)

So, contact with management, solve these problem situations with dialogue, bringing to the improved ones a reflection of what they would do in my place in their workplace, how to involve management... trying to solve it with a conversation between management, staff multidisciplinary and among the trainees. (P2)

In turn, preceptorship can also help in strengthening the autonomy of certified nurse-midwives in the relationship with the team.

We get a little more questioning, the management has to modify to be able to meet what we need in-service. (P6)

Preceptorship in the course gives you arguments, basis, and reflection on the service. (P4)

The management of the units starts to perceive the issue of autonomy of this professional [certified nurse-midwife preceptor], of how much this professional has technical-scientific knowledge and evidence-based practice for this delivery assistance [...] the intervention that the course there is to change the care model, so that certified nurse-midwives have autonomy in delivery care [...] insertion of the nurse's protocol fully in the multidisciplinary team as a highly trained professional. (P2)

It was detailed that this process of expanding the performance and professional autonomy of these specialists, based on the preceptorship in a training course, had as a proposal to carry out actions that characterized intervention. In a way, they caused changes related to institutional work, with a view to the need to meet NMEC/MoH/UFF guidelines.

\section{DISCUSSION}

Due to the fact that they are developing preceptorship activities in a course financed by MoH (NMEC/UFF), certified nursemidwife preceptors, enhanced certified nurse-midwives and other professionals had the need to organize the ways of representing competencies that, in a certain way, allowed dialogues with quality expectations in the training process. Developing the ability to analyze workplace and ways of co-managing from collective practices between and with different professionals made it possible to assess real work situations as a privileged space for training and intervention ${ }^{(11)}$.

Showing strength to create teaching-learning relationships, based on limitations imposed by difficulties in structure/environment and work relationships influenced by the historical corporate mode of action in health due to collective interprofessional actions $^{(22)}$, was also a daily effort performed by certified nursemidwife preceptors in order to guarantee competent training processes. Their activity can contribute to updating of technical knowledge and continuous improvement of quality.

Therefore, this action, which takes into account the reference of external standards of safe practice based on scientific evidence ${ }^{(17)}$, similarly to simulation-enhanced nurse ${ }^{(6-8)}$, also enables to qualify processes of institutional support and intervention in midwifery ${ }^{(23)}$.

It is worth mentioning that each maternity unit that was in the capacity of executing programmed actions saw APICEON/ $\mathrm{MoH}$ as a practical field opportunity for the improvement of certified nurse-midwives from teaching hospitals across the country demonstrated effort. This was done in order to share co-management and training processes interrelated with daily practice, with a view to transforming the work process.

According to the Toolkit for Strengthening Professional Midwifery (2014), support for the improvement or continuous enhancement of quality in midwifery services should provide contribution. Such services must aim for these institutions to commit themselves to assess practices and provide evidence that the activities can be compared with external safety standards, enabling recommendations for the qualification of care ${ }^{(17)}$.

In this perspective, certified nurse-midwife preceptors, when experiencing participative and collaborative actions, gradually inserts into her practice of health care and training, the understanding of institutional support, as a more energizing role than expectative in the process of potentiating institutional changes.

With regard to the training component, professionals not only facilitated the dialogical access to the management, but also provoked the possibility for the manager to position themselves effectively in the face of the existing tensions in the transformation process that were being listed. After all, dealing with professional conflicts, questions, criticisms, and strangeness caused certified nurse-midwife preceptors to incorporate different forces and identify peers, especially with/ within the scope of management, to mediate daily mismatches ${ }^{(19)}$.

Change processes related to professional practice itself were experienced resulting from the need to maintain a closer relationship with management and other team professionals. Thus, commitments, confrontations and mediations in the field of ethical-aesthetic-political values were revealed, which enhanced training with intervention similar to the devices that support decision-making in the care organization process ${ }^{(10,24)}$.

In this way, managers and other professionals perceived themselves faced with the need to solve problems and deal with conflicts, in view of the dialogical-reflexive perspective that was being encouraged in collective meetings with a view to boosting institutional change, from APICEON/MoH and NMEC/MoH/UFF. Thus, not only did they incorporate the interest in sharing examples of competence and innovation, but they also enabled dialogues with the pedagogical proposal of the course. This proposal provoked the critical exercise of collective discussion to try the method of intervention and institutional support in maternity hospitals, starting from the analysis of daily work in dialogue with Paulo Freire theoretical principles ${ }^{(15)}$.

This collective work also represents a place of debate, possibilities and negotiations and, therefore, it is impossible to strictly follow prescriptions/norms, considering that tensions and contradictory enable different meanings to daily relationships in institutions, in a way, contribute to foster processes of change.

Based on scheduled meetings that guaranteed conversations about everyday problems and difficulties, it was possible to use work to experience training/improvement situations from risk classification, through delivery and birth, to discharge in the puerperium. In this way, certified nurse-midwife preceptors had been operating between 
the institutional norm and the renormatization of work processes in a dialogical-reflective relationship in line with the principles of inservice education and the co-management segments. They allowed themselves to reinvent modes of preceptorship, getting involved in support and intervention activities based on the analysis of work, contributing to the transformation of professional life ${ }^{(12-13,25)}$.

In turn, the training path highlighted here, intrinsically related to the modes of management and health care, was pointed out as a strategy that contributed to analyze the ways of work and training in the researched maternity hospitals. Moreover, it made possible collective exchanges of experiences, taking into account the dialogue between technique and human action in an analytical and reflective perspective. Thus, carrying out these activities enabled institutional support strategies, supporting intervention practices in the work process in the units ${ }^{(11)}$.

Therefore, notes, which referred to the actions carried out in the course of updating the service of enhanced certified nursemidwives from all regions of the country, allowed for training based on dialogues and reflections about the daily life in the units of origin of these professionals and the maternities practice field of NMEC/MOH/UFF.

From the exchange of knowledge and experiences, the exercise of preceptorship via NMEC/MoH/UFF made it possible to experience practices that were considered positive to the extent that the use of activities dialoguing with active methodologies in the teaching-learning process, in this case through workshops held in service, allowed certified nurse-midwife preceptors to print a dynamic character in the development of enhancement. Thus, the preceptorship performed by certified nurse-midwives was experienced through discussions about real daily situations, promoted with each group of the course.

The causes and ways of looking at the problems were identified in order to understand and solve them collectively, in addition to ensuring quality in training and continuing education. This perspective, similar to research that dialogs with NHP, confirms contribution to changes in reality. It emphasizes the participatoryemancipatory character of the subjects who appropriately reflect and analytically analyze everyday situations, sharing knowledge production ${ }^{(10)}$. Thus, both care and training, and management professionals began to be invited to rethink their own practice, corroborating indissociability between NHP(2) and PNEPS ${ }^{(18)}$.

In this situation, activities were organized in meetings, whose participation of certified nurse-midwife preceptors allowed to broaden the collective view on the complex institutional relations and to move structural transformations in dialogue with the process of training and co-management ${ }^{(12-13)}$. Furthermore, preceptorship was considered an interesting tool to raise reflections about the importance of alternating the place of speech in the coexistence between workers, prioritizing a culture of reciprocal interests in the organization and interactions in the workplace ${ }^{(10)}$.

To meet the training/improvement needs, there was an intrinsic expansion of attitudes associated with the professional autonomy process, which, in a way, were interesting in solving problem situations related to the development of enhanced certified nurse-midwives. Certified nurse-midwife preceptors, anchored in collective meetings, with a view to intervention and institutional support, managed to expand institutional communicative and dialogical connections. Such connections not only reduced the inequalities of power ${ }^{(19)}$, but also, in a way, raised outcomes that ended up increasing the visibility of professional competence in the NMEC/MoH/UFF-related service.

\section{Study limitations}

The limitation of the present investigation stands out in the absence of systematized records of the activities performed by preceptorship in the maternities involved, such as absence of reports of participation in meetings and preparation of protocols.

\section{Contributions to nursing}

Anchoring teaching-learning relationships through technicalscientific knowledge and updated evidence-based practices raises assessment processes about interventions considered contemporaneously unnecessary in birth and delivery and the process of institutionalization of the certified nurse-midwife's professional practice and qualification of care.

Moreover, the present reflections contributed to strengthen the contemporary image of nurses ${ }^{(26)}$ and to expand their professional autonomy in midwifery, especially in maternity hospitals that were places of practice of NMEC/MoH/UFF across the country.

\section{FINAL CONSIDERATIONS}

Certified nurse-midwife preceptors contributed to in-service training of other nurses specialized in midwifery as a possibility of using improvement/updating in favor of institutional support and intervention in developing work of maternity hospitals, settings of this investigation.

Therefore, it is opportune to characterize that teaching-learning relationships, when experienced in a dialogical-critical-reflexive way from exchanges of information and practices based on updated evidence, they raise self-assessment processes. Such processes, in turn, expand not only the certified nurse-midwife trainee's autonomy in maternity hospitals, which were the fields of practice, but of institutions across the country that sent nurses to perform NMEC, funded by $\mathrm{MoH}$ and carried out by UFF in Niterói, Rio de Janeiro, Brazil.

With this regard, sharing knowledge between preceptors and trainees beyond technocratic repetitions and encouraging collective meetings, from a perspective of democratic co-management, provides opportunities to analyze training, care/assistance, and management work, which characterized intervention and institutional support.

\section{FUNDING}

This research came from a project financed by $\mathrm{MoH}$, Brazil (3969/2018) and operated by the Universidade Federal Fluminense/ Fundação Euclides da Cunha, during the years 2018 and 2019.

\section{ACKNOWLEDGMENT}

We would like to thank the certified nurse-midwife preceptors and enhanced certified nurse-midwives for having contributed to the process of professional enhancement/updating shared during NMEC/MoH/UFF. 


\section{REFERENCES}

1. World Health Organization (WHO). WHO recommendations Intrapartum care for a positive childbirth experience. Geneva: World Health Organization; 2018. 200p.

2. Alves AG, Martins CA, Lima e Silva F, Alexandre MSA, Correa CIN, Tobias GC. Política de humanização da assistência ao parto como base à implementação rede cegonha: revisão integrativa. Rev Enferm UFPE. 2017;11(2):691-702. doi: 10.5205/reuol.10263-91568-1-RV.1102201724

3. Silva LNM, Silveira APKF, Morais FRR. Programa de humanização do parto e nascimento: aspectos institucionais na qualidade da assistência. Rev Enferm UFPE. 2017;11(S8):3290-4. doi: 10.5205/reuol.11135-99435-1-ED.1108sup201713

4. Carvalho EMP, Göttems LBD, Pires MRGM. Adesão às boas práticas na atenção ao parto normal: construção e validação de instrumento. Rev Esc Enferm USP. 2015;49(6):889-897. doi: 10.1590/S0080-623420150000600003

5. Medeiros RMK, Teixeira RC, Nicolini AB, Alvares AS, Corrêa ACP, Martins DP. Humanized care: insertion of obstetric nurses in a teaching hospital. Rev Bras Enfermagem. 2016;69(6):1029-36. doi: 10.1590/0034-7167-2016-0295

6. Nanette I. Vogel, enhancing the competency of obstetric nurses in the perioperative environment. J Obstetr, Gynecol Neonatal Nurs. 2018;47(Supp-3). doi: 10.1016/j.jogn.2018.04.041

7. Raney J, Morgan MC, Christmas A, Sterling M, Spindler H, Ghosh R, et al. Simulation-enhanced nurse mentoring to improve preeclampsia and eclampsia care: an education intervention study in Bihar, India. BMC Pregnancy Childbirth. 2019;19:41. doi: 10.1186/s12884-019-2186-x

8. Guimond ME. "Evaluation Of A Simulation-enhanced Obstetric Clinical Experience On Learning Outcomes For Knowledge, Self-efficacy, And Transfer" [Internet] . Electronic Theses and Dissertations. 2010[cited 2019 Aug 21]. University of Central Florida Libraries. Available from: http://library.ucf.edu

9. Ministério da Saúde (BR). APICEON - Aprimoramento e Inovação no Cuidado e Ensino em Obstetrícia e Neonatologia. Secretaria de Atenção à Saúde. Departamento de Ações Programáticas e Estratégicas. Brasília: Ministério da Saúde; 2017. 31 p.

10. Santos Filho SB. Apoio institucional e análise do trabalho em saúde: dimensões avaliativas e experiências no Sistema Único de Saúde (SUS). Interface. 2014;18(Supl-1):1013-25. doi: 10.1590/1807-57622013.0159

11. Roza MMR, Barros MEB, Guedes CR, Santos Filhos SB. A experiência de um processo de formação articulando humanização e apoio institucional no trabalho em saúde. Interface. 2014;18(Supl-1):1041-52. doi: 10.1590/1807-57622013.0199

12. Fontoura AMT. Arranjos e estratégias de Cogestão em maternidades públicas[Dissertação]. Rio de Janeiro; 2017.

13. Mori ME, Oliveira OVM. Apoio institucional e cogestão: a experiência da Política Nacional de Humanização no Sistema Único de Saúde (SUS) no Distrito Federal, Brasil. Interface. 2014;18(Supl-1):1063-1075. doi: 10.1590/1807-57622013.0316

14. Miccas FL, Batista SHSS. Educação permanente em saúde: metassíntese. Rev Saúde Pública. 2014;48(1):170-85. doi: 10.1590/ S0034-8910.2014048004498

15. Freire AMA, (org.). Paulo Freire - Pedagogia do compromisso: América Latina e educação popular. Rio de Janeiro-São Paulo: Paz \&Terra; 2018.

16. Ferreira FG, Dantas FC, Valente GSC. Saberes e competências do enfermeiro para preceptoria em unidade básica de saúde. Rev Bras Enferm. 2018;71(4):1657-65. doi: 10.1590/0034-7167-2016-0533

17. Organização Panamericana de Saúde (OPAS). Conjunto de ferramentas para o fortalecimento da parteria nas Américas. Centro LatinoAmericano de Perinatologia, Saúde da Mulher e Reprodutiva, Montevidéu: CLAP/SMR, 2014.

18. Ministério da Saúde (BR). Secretaria de Gestão do Trabalho e da Educação na Saúde. Departamento de Gestão da Educação na Saúde. Política Nacional de Educação Permanente em Saúde: o que se tem produzido para o seu fortalecimento? Brasília. Brasília: Ministério da Saúde, 2018.73p.

19. Pereira AV, Roterberg L, Oliveira SS. Relações de gênero e interdependências: reflexões a partir de mudanças na configuração hospitalar. Hist Ciên Saúde: Manguinhos. 2013;20(3):1007-24. doi: 10.1590/S0104-59702013005000009

20. Tong A, Sainsbury P, Craig J. Consolidated criteria for reporting qualitative research (COREQ): a 32-item checklist for interviews and focus groups. Int J Qual Health Care. 2007;19(6):349-57. doi: 10.1093/intqhc/mzm042

21. Bardin L. Análise de conteúdo. Lisboa: Edições 70. 2011. (Trabalho original publicado em 1977).

22. Pereira AV. Tutoria interprofissional no Programa de Educação pelo Trabalho para a Saúde - Rede Cegonha: desafios de uma experiência realizada no município de Niterói-RJ. In: Abrahão AL, Souza AC. (Org.). Composições de formação em saúde: a experiência do PET-UFF. São Paulo: Hucitec, 2019. p. 89-99.

23. Andrade MAC, Barros SMM, Maciel NP, Sodré F, Lima RCD. Institutional support: democratic strategy in the everyday practices of the Brazilian Health System (SUS). Interface (Botucatu). 2014;18(Supl-1):833-44. doi: 10.1590/1807-57622013.0222

24. Nkwanyana, NM, Voce AS. Are there decision support tools that might strengthen the health system for perinatal care in South African district hospitals? a review of the literature. BMC Health Serv Res. 2019;19:731. doi:10.1186/s12913-019-4583-2

25. Vasconcelos MFF, Martins CP, Machado DO. Apoio institucional como fio condutor do Plano de Qualificação das Maternidades: oferta da Política Nacional de Humanização em defesa da vida de mulheres e crianças brasileiras. Interface. 2014;18(supl-1):997-1011. doi: 10.1590/1807-57622013.0335

26. Pereira AV. Relações de gênero no trabalho: reflexões a partir de imagens construídas de enfermeiras e enfermeiros. Cad Espaço Fem [Internet]. 2011 [cited 2019 Aug 21];21(1). Available from: http://www.seer.ufu.br/index.php/neguem/article/view/14218 